\title{
Assessment of Heavy Metals Pollution in Sediments from Ologe Lagoon, Agbara, Lagos, Nigeria
}

\author{
Moyosoluwa Odunayo Adeyemi' ${ }^{1}$ Johnson Adedeji Olusola², Oghenemaro Akpobasah'1, \\ Nathan Eyituoyo Adidi ${ }^{1}$, Rafiu Olaniyi Dada Shelle ${ }^{3}$ \\ ${ }^{1}$ Department of Geology, Crawford University, Igbesa, Nigeria \\ ${ }^{2}$ Department of Geography and Planning Science (Environmental Management Option), Ekiti State University, Ado Ekiti, Nigeria \\ ${ }^{3}$ Nigerian Institute for Oceanography and Marine Research (NIOMR), Victoria Island, Lagos, Nigeria \\ Email: moyo_adeyemi@yahoo.com
}

How to cite this paper: Adeyemi, M. O., Olusola, J. A., Akpobasah, O., Adidi, N. E., \& Shelle, R. O. D. (2019). Assessment of Heavy Metals Pollution in Sediments from Ologe Lagoon, Agbara, Lagos, Nigeria. Journal of Geoscience and Environment Protection, 7, 61-73.

https://doi.org/10.4236/gep.2019.77006

Received: April 19, 2019

Accepted: July 21, 2019

Published: July 24, 2019

Copyright $\odot 2019$ by author(s) and Scientific Research Publishing Inc. This work is licensed under the Creative Commons Attribution International License (CC BY 4.0).

http://creativecommons.org/licenses/by/4.0/

(c) (i) Open Access

\begin{abstract}
This study was carried out to assess the level of heavy metals pollution in Ologe Lagoon, Agbara, Lagos, Nigeria. The Lagoon receives effluents from industries in the Agbara Industrial Estate. Cored Soft sediments were retrieved from six random sampling points within the Lagoon and labeled (S1, S2, S3, S4, S5 and S6). Subsamples of the sediments were prepared and analyzed for heavy metal concentration. The result from the heavy metal analysis of the sediments shows that average concentration of $\mathrm{Mn}, \mathrm{Zn}, \mathrm{Cr}, \mathrm{Ni}, \mathrm{Cr}, \mathrm{Ni}, \mathrm{Co}, \mathrm{Cu}$ and $\mathrm{Pb}$ in the samples was $278.1 \mathrm{ppm}, 21.7 \mathrm{ppm}, 14.2 \mathrm{ppm}, 6.6 \mathrm{ppm}, 6.4 \mathrm{ppm}, 6.4 \mathrm{ppm}$ and $4.4 \mathrm{ppm}$, respectively. The correlation between the heavy metals varies from 0.71 to 0.98 shows that they have a strongly positive degree of association which suggests that they are from the same source. The geo-accumulation values for $\mathrm{Cu}$ in all stations ranged between $(1-2.8 \mathrm{ppm})$ and it can be deduced that the sediments are moderately to strongly polluted. $\mathrm{Pb}$ varies between 1 and 2.1 suggesting that the sediments are moderately polluted. $\mathrm{Zn}$ exhibits strong pollution levels with a range from 2.5 and $3.5 \mathrm{ppm}$. Co is moderately polluted with $1.5-2.4$ while $\mathrm{Mn}$ shows the highest level of pollution in all stations with $\mathrm{I}_{\mathrm{geo}}$ values ranging between 4.1 and 5.8. This study showed that the Lagoon accumulates heavy metals as a result of anthropogenic activities evident in the dumping of municipal, sewage, industrial waste in the environment and domestic activities such as auto mobile transportation and mechanic repair workshop. Based on sediment quality guidelines, the Ologe Lagoon level of pollution ranged from $\mathrm{Cu}>$ $\mathrm{Pb}>\mathrm{Zn}>\mathrm{Ni}>\mathrm{Co}>\mathrm{Mn}>\mathrm{Cr}>\mathrm{Al}$ with Mn having the highest level of pollution.
\end{abstract}

\section{Keywords}

Heavy Metals, Wet Environments, Geo-Accumulation Index, Ologe Lagoon 


\section{Introduction}

The rapid growth of industrialization and population in Nigeria has brought about the problem of pollution in the natural environment. Heavy metals are naturally occurring elements with high atomic weight and a density about five times more than that of water (Duffus, 2002). Heavy metals are toxic and their multiple industrial, domestic, agricultural, medical and technological applications have led to a geometric increase in the ecosystem, especially the wetlands which serve as sinks for pollutants (Ita \& Anwana, 2017). Heavy metals toxicity and distribution in wetlands can disrupt the ecosystem of the soil and that of the aquatic flora and fauna which depend on it and in turn pose a threat to human health (Loizidou et al., 1992).

Metals such as copper $(\mathrm{Cu})$, chromium $(\mathrm{Cr})$, Zinc $(\mathrm{Zn})$, Iron $(\mathrm{Fe})$ and Manganese $(\mathrm{Mn})$ are essential micronutrients required for plant and animal metabolism but can become toxic at high concentrations (Bryan, 1976). Arsenic (As), cadmium $(\mathrm{Cd})$, chromium $(\mathrm{Cr})$, lead $(\mathrm{Pb})$, and mercury $(\mathrm{Hg})$ have a negative effect on the ecosystem; they are highly toxic and rank among the priority metals that are of public health significance (Zheng et al., 2007; Duffus, 2002). Naturally occurring heavy metals are found throughout the earth's crust. They are released into the environment from the weathering of rocks. The average concentration of naturally occurring heavy metal in sediments can serve as the baseline level of heavy metal concentration (Smith, 1985; Alloway, 2012; Hariprasad \& Dayananda, 2013). Anthropogenic activities are considered the major sources of heavy metal pollution on the earth surface (Connell et al., 1999; Bosman \& Kidd, 2009). Environmental contamination and human exposure to toxic heavy metals are predominantly as a result of anthropogenic activities such as mining and smelting operations, industrialization, and the domestic and agricultural use of metallic compounds. Therefore, the aim of this study is to assess the level of heavy metal pollution using sediments from Ologe Lagoon, Lagos State, Nigeria.

\section{Materials and Methods}

\section{Study Area}

Ologe Lagoon is a freshwater lagoon; it is amongst the four major lagoons in Lagos State, southwestern Nigeria together with Epe, Lekki and Lagos Lagoons. Ologe Lagoon had an area expanse of $9.4 \mathrm{~km}^{2}$ with coordinates between latitudes $6^{\circ} 27^{\prime} \mathrm{N}$ and $6^{\circ} 30^{\prime} \mathrm{N}$; longitudes $3^{\circ} 02^{\prime} \mathrm{E}$ and $3^{\circ} 07^{\prime} \mathrm{E}$ (Figure 1). River Owo is the major source of fresh water and sediments into the lagoon before it discharges into the Atlantic Ocean through the Lagos Harbor and the Badagry Creek (Anetekhai et al., 2007; Kusemiju et al., 2001; Kumolu-Johnson et al., 2010). The lagoon receives industrial waste and effluents from the Agbara Industrial Estate. The study area has a climate regime with a dominant wet season between March and November with an average rainfall of $154 \mathrm{~m}$. The vegetation is of an equatorial rain forest and characterized by a fresh water mangrove swamp. The vegetation cover remains evergreen throughout the year and is mostly inaccessible. 


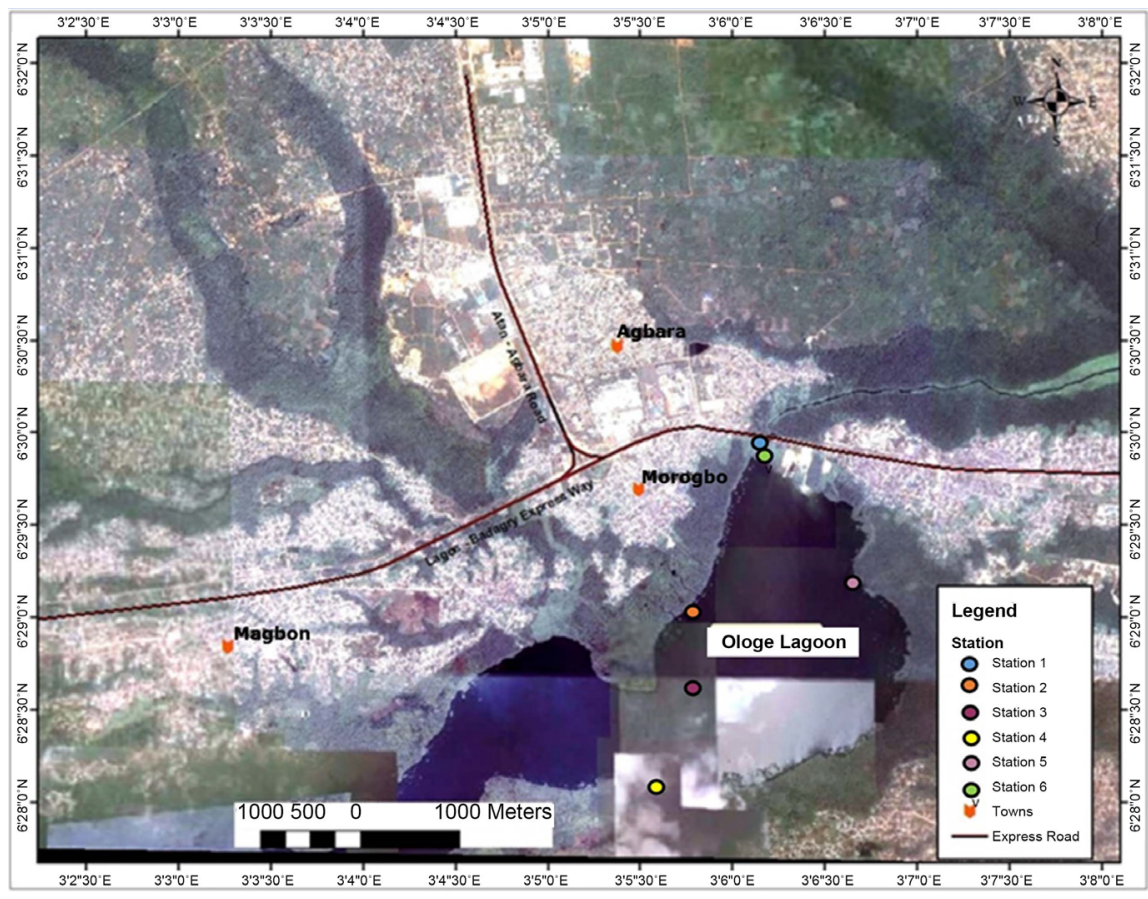

Figure 1. Aerial photograph showing sampling points within the Ologe lagoon.

Soil type is hydromorphic and they are seasonally or permanently water logged. The soil has dull colors, often brown, reddish-brown or dark grey at the surface. Station 1 was situated close to the contact between the Lagoon and the Agbara community. Anthropogenic activities going on in this area include; sand dredging, refuse dumping, and effluents discharge from the industries in Agbara.

\section{Methodology}

\subsection{Sample Collection and Preparation}

Sampling and collection was carried out within Ologe Lagoon with the use of a boat as a means of transportation. Six sampling points (S1, S2, S3, S4, S5 and S6) were picked within the lagoon and the coordinates were recorded using a Global Positioning System (GPS) Table 1. Bottom sediments from the lagoon were collected with the aid of a soft sediment Piston corer. The retrieved cores $(40 \mathrm{~cm})$ were divided at depth of $0-10 \mathrm{~cm}, 10-20 \mathrm{~cm}, 20-30 \mathrm{~cm}$ and $30-40 \mathrm{~cm}$ into samples into 4 samples labeled A, B, C and D, respectively. The samples retrieved from the cores were then stored in plastic containers which were adequately labeled and taken to the laboratory for sample preparation. The samples were dried in the open air for 2 weeks in the laboratory, after which they were pulverized using a mortar and pestle. Subsamples of $2 \mathrm{~g}$ were collected in well labeled air tight containers before being sent for elemental compositional analyses at Bureau Veritas Commodities Canada Limited.

\subsection{Geochemical Analysis}

Heavy metals in the sediments were determined using Induced Coupled Plasma 
Table 1. Coordinates of the sampling stations in the study area.

\begin{tabular}{ccc}
\hline Station & Latitude & Longitude \\
\hline S1 & $6^{\circ} 29^{\prime} 57.5^{\prime \prime}$ & $3^{\circ} 6^{\prime} 10.3^{\prime \prime}$ \\
S2 & $6^{\circ} 29^{\prime} 1.9^{\prime \prime}$ & $3^{\circ} 5^{\prime} 45.3^{\prime \prime}$ \\
S3 & $6^{\circ} 28^{\prime} 34.6^{\prime \prime}$ & $3^{\circ} 5^{\prime} 32.4^{\prime \prime}$ \\
S4 & $6^{\circ} 28^{\prime} 4.4^{\prime \prime}$ & $3^{\circ} 5^{\prime} 35.3^{\prime \prime}$ \\
S5 & $6^{\circ} 29^{\prime} 12.32^{\prime \prime}$ & $3^{\circ} 6^{\prime} 38.7^{\prime \prime}$ \\
S6 & $6^{\circ} 29^{\prime} 12.32^{\prime \prime}$ & $3^{\circ} 6^{\prime} 38.7^{\prime \prime}$ \\
\hline
\end{tabular}

Emission Spectroscopy/Mass Spectroscopy (ICP-ES/MS). Subsamples with $<75$ $\mu \mathrm{m}$ fractions were used for the geochemical analysis. About $0.5 \mathrm{~g}$ of the pulp was weighed into the digestion flask and mixed with Aqua Regia (mixture of $0.5 \mathrm{ml}$ $\mathrm{H} 2 \mathrm{O}, 0.6 \mathrm{ml}$ concentrated $\mathrm{HNO}_{3}$ and $1.8 \mathrm{ml}$ concentrated $\mathrm{HCl}$ ) for about two hours at a temperature of $80^{\circ} \mathrm{C}$ to $95^{\circ} \mathrm{C}$. The mixture was cooled and then diluted to $10 \mathrm{ml}$ of de-ionized water to homogenize the liquid. The digestion method using Aqua Regia has been confirmed to be able to leach out all adsorbed metals from sediment without necessarily attacking the silicate structure of the solids. It thus makes it possible to measure the quantity of metals present with greater accuracy and the metals are made easily available for bioaccumulation. This method has the ability to leach sulphides, some oxides and silicates, the mineral phases that are rarely attacked include barite, zircon, monazite, sphene, chromites, garnet, ilmenite, rutile and cassiterite (Scott et al., 1972).

\subsection{Data Analysis}

The level of heavy metal contamination in the sediments was assessed with the use of the enrichment factor (EF), Contamination Factor (CF), Geo-accumulation Index $\left(\mathrm{I}_{\mathrm{geo}}\right)$ as quantitative indices.

\subsubsection{Enrichment Factor (EF)}

This can be defined as the minimum factor by which the weight percent of elements in a body is greater than the average occurrence of that mineral in the earth's crust (Sinex \& Helz, 1981). It can be used to compare and contrast different areas. Enrichment factor was used to determine the level of enrichment of Ologe Lagoons sediments. Quality of the sediments from the environment was determined by comparing the metal content in the sediments and the officially permitted levels such as (USEPA, 1999). The formula is expressed as:

$$
\mathrm{EF}=\frac{\mathrm{Me} / \mathrm{Al}_{\text {(sample) }}}{\mathrm{Me} / \mathrm{Al}_{\text {(background) }}}
$$

where; $\mathrm{Me} / \mathrm{Al}_{\text {(sample) }}$ represents the metal to $\mathrm{Al}$ ratio in the sample of interest and $\mathrm{Me} / \mathrm{Al}_{\text {(background) }}$ is the natural background value of metal to $\mathrm{Al} \mathrm{ratio.} \mathrm{As} \mathrm{we} \mathrm{do} \mathrm{not}$ have metal background values for our study area, we used the values from World Average Shale. Aluminum was selected as the element of normalization because 
it's predominant in natural sources of sediments (Tippie, 1984) and Average Shale Values proposed by (Mmolawa et al., 2011) were used as the background values. The classification used is presented in Table 2 .

\subsubsection{Contamination Factor (CF)}

The assessment of the degree of heavy metal contamination in the sediments was carried out using the Contamination Factor (CF) which can be expressed as:

$$
\mathrm{CF}=\frac{C_{\text {heavymetal }}}{C_{\text {background }}}
$$

Hakanson (1980) categorized the contamination factor into 6 categories, CF < 1 is low contamination; $1 \geq \mathrm{CF} \geq 3$ is moderate contamination; $3 \geq \mathrm{CF} \geq 6$ is considerable contamination; $\mathrm{CF} \geq 6$ is very high contamination.

\subsubsection{Geo-Accumulation Index ( $I_{g e o}$ )}

Geo-accumulation Index as proposed by Muller (1969) was used to classify the degree of heavy metal contamination in the sediments (Table 3 ). The formula is expressed as:

$$
\mathrm{I}_{\text {geo }}=\log _{2}\left(\frac{C_{n_{\text {sample }}}}{1.5 * B_{n_{\text {background }}}}\right)
$$

$C_{n}=$ Measured concentration of heavy metals in the soil samples.

$B_{n}=$ Average shale value.

\subsection{Statistical Analysis}

The results obtained from geochemical analysis were subjected to statistical treatment. Both univariate and multivariate analysis were done using SPSS (Statistical program for the social scientists) and Microsoft excel.

\section{Correlation and Component Analysis}

The importance of Principal Component matrix is for data reduction and also to identify the source of the metals in the sediments, Table 4 showed 2 factors. The first component were sourced from both anthropogenic and geogenic origin due to the fact that certain elements which do not naturally occur in the environment are present alongside those that are naturally deposited, while series 2 shows only geogenic origin due to the fact that the element in this series mostly alkali earth metals which are gotten from calcareous fossil deposit.

Table 2. Enrichment factor categories (Mmolawa et al., 2011).

\begin{tabular}{cc}
\hline Enrichment Factor (EF) & Categories \\
\hline $\mathrm{EF}<2$ & Deficiency to minimal enrichment \\
$2 \leq \mathrm{EF}<5$ & Moderate enrichment \\
$5 \leq \mathrm{EF}<20$ & Significant enrichment \\
$20 \leq \mathrm{EF}<40$ & Very high enrichment \\
$\mathrm{EF} \geq 40$ & Extremely high enrichment \\
\hline
\end{tabular}


Table 3. Showing the classification of geo-accumulation index (Muller, 1969).

\begin{tabular}{cc}
\hline Values & Quality \\
\hline $\mathrm{I}_{\text {geo }}<0$ & Unpolluted \\
$0<\mathrm{I}_{\text {geo }}<1$ & Unpolluted to moderately polluted \\
$1<\mathrm{I}_{\text {geo }}<2$ & Moderately polluted \\
$2<\mathrm{I}_{\text {geo }}<3$ & Moderately polluted to highly polluted \\
$3<\mathrm{I}_{\text {geo }}<4$ & Highly polluted \\
$4<\mathrm{I}_{\text {geo }}<5$ & Highly polluted to very highly polluted \\
$5<\mathrm{I}_{\text {geo }}$ & Very highly polluted \\
\hline
\end{tabular}

Table 4. Concentration of major and trace elements present in Ologe Lagoon in comparison with other background values.

\begin{tabular}{|c|c|c|c|c|c|}
\hline & & & \multicolumn{3}{|c|}{ Concentration in reference materials } \\
\hline & Range & Mean \pm SD & UCC & ACC & ASV \\
\hline $\mathrm{Ca}$ & $0.02-1.3$ & $0.31 \pm 0.35$ & 2.99 & 5.29 & \\
\hline $\mathrm{Ti}$ & $0.01-0.03$ & $0.02 \pm 0.01$ & & & \\
\hline $\mathrm{Al}$ & $0.1-1.97$ & $0.70 \pm 0.58$ & 8.03 & 8.42 & \\
\hline $\mathrm{Na}$ & $0.01-0.25$ & $0.09 \pm 0.08$ & & & \\
\hline $\mathrm{K}$ & $0.01-0.25$ & $0.07 \pm 0.07$ & 2.81 & 1.08 & \\
\hline $\mathrm{P}$ & $0-0.08$ & $0.02 \pm 0.02$ & & & \\
\hline $\mathrm{Mg}$ & $0.01-0.55$ & $0.16 \pm 0.17$ & 1.32 & 3.18 & \\
\hline S & $0.10-5.21$ & $1.25 \pm 1.45$ & & & \\
\hline Mo & $0.5-73.1$ & $8.63 \pm 19.94$ & & & \\
\hline As & $5.0-5.0$ & $5.00 \pm 0.00$ & 1.5 & 1 & \\
\hline $\mathrm{U}$ & $0.8-13.9$ & $3.38 \pm 4.46$ & & & \\
\hline Th & $0.5-7.6$ & $2.84 \pm 2.25$ & & & \\
\hline $\mathrm{Sr}$ & $6.0-95$ & $34.53 \pm 25.94$ & & & \\
\hline $\mathrm{V}$ & $13-65$ & $28.75 \pm 20.90$ & & & \\
\hline $\mathrm{La}$ & $1.2-21.2$ & $7.21 \pm 6.08$ & & & \\
\hline $\mathrm{Cr}$ & $2.2-44.2$ & $14.22 \pm 13.15$ & 85 & 185 & \\
\hline $\mathrm{Ba}$ & $9-109$ & $32.78 \pm 28.80$ & & & \\
\hline $\mathrm{Hg}$ & $0.06-0.21$ & $0.13 \pm 0.08$ & & & \\
\hline $\mathrm{Sc}$ & $0.5-7.5$ & $2.57 \pm 2.00$ & & & \\
\hline $\mathrm{Tl}$ & $0.5-0.7$ & $0.60 \pm 0.10$ & & & \\
\hline $\mathrm{Ga}$ & $5.0-7.0$ & $6.25 \pm 0.96$ & & & \\
\hline $\mathrm{Cu}$ & $0.5-20.9$ & $6.43 \pm 6.20$ & 25 & 75 & 45 \\
\hline $\mathrm{Pb}$ & $0.7-11$ & $4.49 \pm 3.48$ & 17 & 8 & 20 \\
\hline $\mathrm{Zn}$ & $5.0-46.0$ & $26.44 \pm 14.06$ & & & 5 \\
\hline $\mathrm{Ni}$ & $0.8-21.4$ & $6.69 \pm 6.00$ & 44 & 105 & 68 \\
\hline Co & $2.2-17.1$ & $6.44 \pm 4.28$ & 17 & 29 & 19 \\
\hline $\mathrm{Mn}$ & $14-1039$ & $278.13 \pm 343.44$ & 500 & 1400 & 850 \\
\hline
\end{tabular}




\section{Results and Discussions}

\subsection{Geochemical Analysis}

The concentration of 30 elements (Ag, As, U, Mo, Cd, Sb, Bi, V, W, Hg, Ti, Ga, $\mathrm{Se}, \mathrm{K}, \mathrm{Ca}, \mathrm{P}, \mathrm{La}, \mathrm{Mg}, \mathrm{Ba}, \mathrm{Ti}, \mathrm{Cr}, \mathrm{U}, \mathrm{Zn}, \mathrm{Ni}, \mathrm{Co}, \mathrm{Mn}, \mathrm{Fe}$. Th, Sr, and Mo) were determined. Thirteen elements had concentrations below detection limits in some sediments samples: $\mathrm{Ag}$ (0.5 ppm), As (5 ppm), U (0.5 ppm), Mo (0.5 ppm), Cd (0.5 ppm), Sb (0.5 ppm), Bi (0.5 ppm), V (10 ppm), W (0.5 ppm), Hg (0.05), Ti $(0.5 \mathrm{ppm}), \mathrm{Ga}(5 \mathrm{ppm})$ and $\mathrm{Se}(2 \mathrm{ppm})$. Seven toxic metals (Co, $\mathrm{Cu}, \mathrm{Cr}, \mathrm{Ni}, \mathrm{Zn}$, $\mathrm{Mn}$, and $\mathrm{Pb}$ ) were considered for the assessment of heavy metal pollution in the lagoon. The statistics of the results of the geochemical analysis of the sediments together with other reference values are presented in Table 4 . The heavy metal ranges for the average concentrations in the stations are $\mathrm{Cu}(2.63-18.63 \mathrm{ppm})$, $\mathrm{Pb}$ (2.08 - $9.98 \mathrm{ppm}), \mathrm{Zn}(15.50$ - $45.00 \mathrm{ppm}), \mathrm{Ni}(2.50$ - $17.60 \mathrm{ppm})$, Co (3.23 $12.53 \mathrm{ppm}), \mathrm{Mn}(70.50-839.50 \mathrm{ppm})$ and $\mathrm{Cr}(4.58-39.20 \mathrm{ppm})$. The order of abundance of heavy metals in the six sample stations are as follows; S1: Mn > $\mathrm{Zn}>\mathrm{Cr}>\mathrm{Cu}>\mathrm{Ni}>\mathrm{Co}>\mathrm{Pb}$; $\mathrm{S} 2 \mathrm{Mn}>\mathrm{Zn}>\mathrm{Cr}>\mathrm{Co}>\mathrm{Ni}>\mathrm{Pb}>\mathrm{Cu}$; $\mathrm{S}: \mathrm{Mn}>$ $\mathrm{Zn}>\mathrm{Cr}>\mathrm{Co}>\mathrm{Cu}>\mathrm{Ni}>\mathrm{Pb}$; 4 : $\mathrm{Mn}>\mathrm{Zn}>\mathrm{Cr}>\mathrm{Co}>\mathrm{Pb}>\mathrm{Ni}>\mathrm{Cu}$; $5: \mathrm{Mn}>$ $\mathrm{Zn}>\mathrm{Cr}>\mathrm{Cu}>\mathrm{Co}>\mathrm{Ni}>\mathrm{Pb}$; $\mathrm{S} 6: \mathrm{Mn}>\mathrm{Zn}>\mathrm{Cr}>\mathrm{Ni}>\mathrm{Co}>\mathrm{Cu}>\mathrm{Pb}$.

In Station $1, \mathrm{Cu}$ and $\mathrm{Ni}$ have concentration above the USEPA standards (USEPA, 1999). A plot showing the distribution of major elements and heavy metals concentration is presented in Figure 2. The plot shows that Station 1 has higher abundance of elements which could be as a result of the proximity of the sampling point to the Agbara industrial estate. The average heavy metal concentrations from the Sampling points were compared with geochemical background values
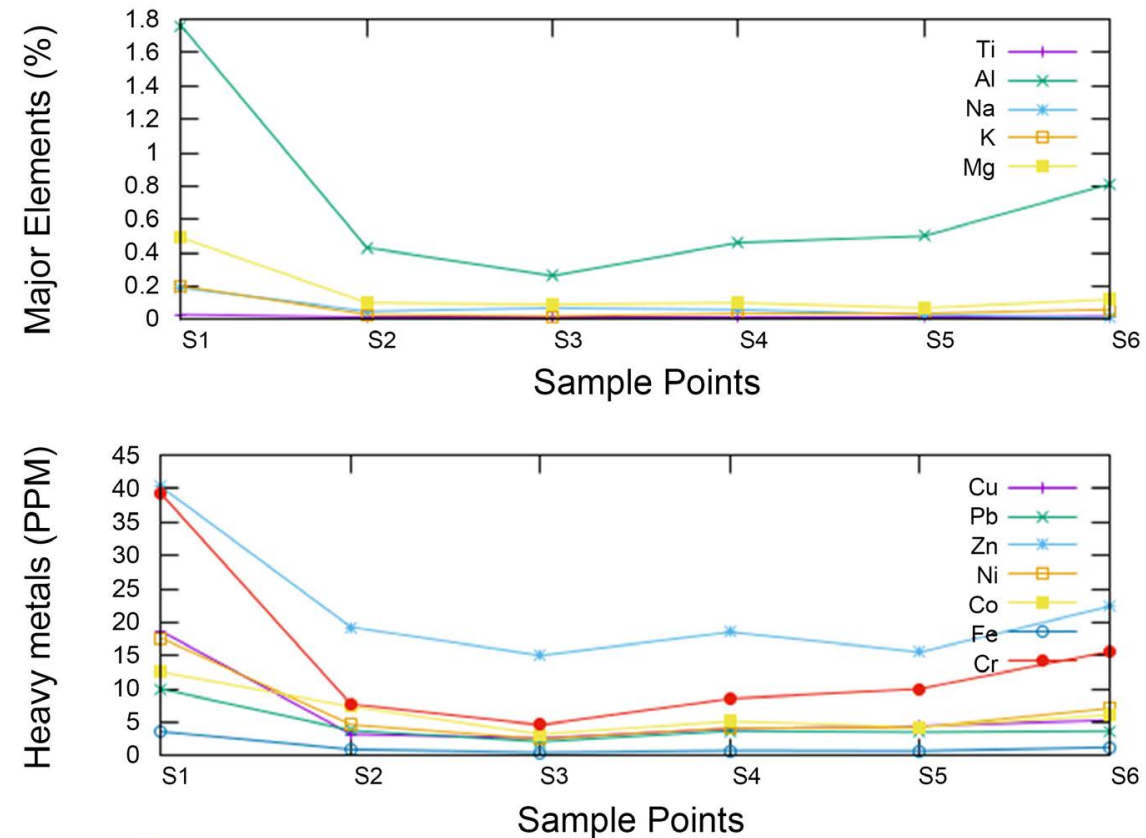

Figure 2. Distribution pattern of major elements and heavy metals concentration across the six sampling points. 
such as United State Environmental Protection Agency Standard (USEPA, 1999) and the Average Shale Value (Turekian \& Wedepohl, 1961). The concentration of $\mathrm{Mn}$ in Station 1 is higher than the global average shale values and the United State Environmental Protection Agency. The enrichment suggests contributions from anthropogenic activities such as smelting and industrial effluents. $\mathrm{Pb}$ (avg. $4.49 \mathrm{ppm}$ ) has the lowest concentration highest in the sediments.

The correlation exercise shows a strong degree of association between all the elements and $\mathrm{Al}$ suggesting that the elements in Ologe Lagoon have a common source except for $\mathrm{Ca}, \mathrm{Ba}$ and $\mathrm{P}$ (Table 5). The principal component analysis is presented in Table 6 and the analysis shows that the elements can be divided into two components. Predominant elements in Component 1 are $\mathrm{Al}, \mathrm{K}, \mathrm{Sc}, \mathrm{Cr}$, $\mathrm{Th}, \mathrm{Fe}, \mathrm{Ni}, \mathrm{Cu}$ and $\mathrm{S}$ which accounted for a total variance of about $79.71 \%$ in the data matrix. The strong degree of association of Component 1 with Fe, Mn and $\mathrm{Al}$ suggests that the elements are geogenic in origin and likely product of weathering and erosion of rocks (Mico et al., 2006; Bloomfield et al., 1976). Component 2 elements are $\mathrm{Ba}, \mathrm{Ca}$ and $\mathrm{P}$ which account for a total variance of about $13.40 \%$ and the sources are more likely to be from biological processes in the marine environment.

The concentration distribution of heavy metals across vertical profiles retrieved from cores samples of soft sediments at S1, S2, S3, S4, S5 and S6 within

Table 5. The correlation of elements in sediments from Ologe lagoon.

\begin{tabular}{|c|c|c|c|c|c|c|c|c|c|c|c|c|c|c|c|c|c|c|}
\hline & $\mathrm{Cu}$ & $\mathrm{Pb}$ & $\mathrm{Ni}$ & Co & $\mathrm{Mn}$ & $\mathrm{Fe}$ & Th & $\mathrm{Ca}$ & $\mathbf{P}$ & $\mathrm{La}$ & $\mathrm{Cr}$ & $\mathrm{Mg}$ & $\mathrm{Ba}$ & $\mathrm{Ti}$ & $\mathrm{Al}$ & $\mathbf{K}$ & Sc & $S$ \\
\hline $\mathrm{Cu}$ & 1.0 & & & & & & & & & & & & & & & & & \\
\hline $\mathrm{Pb}$ & 0.9 & 1.0 & & & & & & & & & & & & & & & & \\
\hline $\mathrm{Ni}$ & 1.0 & 0.9 & 1.0 & & & & & & & & & & & & & & & \\
\hline Co & 0.8 & 0.9 & 0.8 & 1.0 & & & & & & & & & & & & & & \\
\hline $\mathrm{Mn}$ & 0.9 & 0.9 & 0.8 & 0.7 & 1.0 & & & & & & & & & & & & & \\
\hline $\mathrm{Fe}$ & 0.9 & 0.9 & 0.9 & 0.9 & 0.8 & 1.0 & & & & & & & & & & & & \\
\hline Th & 1.0 & 0.8 & 1.0 & 0.8 & 0.8 & 0.9 & 1.0 & & & & & & & & & & & \\
\hline $\mathrm{Ca}$ & 0.4 & 0.7 & 0.4 & 0.6 & 0.7 & 0.5 & 0.3 & 1.0 & & & & & & & & & & \\
\hline $\mathbf{P}$ & 0.6 & 0.8 & 0.6 & 0.7 & 0.8 & 0.6 & 0.5 & 0.9 & 1.0 & & & & & & & & & \\
\hline $\mathrm{La}$ & 1.0 & 0.9 & 1.0 & 0.8 & 0.9 & 0.9 & 1.0 & 0.5 & 0.7 & 1.0 & & & & & & & & \\
\hline $\mathrm{Cr}$ & 1.0 & 0.9 & 1.0 & 0.8 & 0.8 & 0.9 & 1.0 & 0.3 & 0.6 & 1.0 & 1.0 & & & & & & & \\
\hline $\mathrm{Mg}$ & 1.0 & 0.9 & 1.0 & 0.8 & 0.9 & 0.9 & 0.9 & 0.5 & 0.7 & 1.0 & 0.9 & 1.0 & & & & & & \\
\hline $\mathrm{Ba}$ & 0.2 & 0.5 & 0.3 & 0.5 & 0.5 & 0.3 & 0.1 & 0.9 & 0.7 & 0.3 & 0.2 & 0.3 & 1.0 & & & & & \\
\hline $\mathrm{Ti}$ & 0.9 & 0.7 & 0.9 & 0.6 & 0.7 & 0.8 & 0.9 & 0.2 & 0.4 & 0.9 & 0.9 & 0.8 & 0.1 & 1.0 & & & & \\
\hline $\mathrm{Al}$ & 1.0 & 0.9 & 1.0 & 0.8 & 0.8 & 0.9 & 1.0 & 0.4 & 0.6 & 1.0 & 1.0 & 1.0 & 0.2 & 0.9 & 1.0 & & & \\
\hline $\mathrm{K}$ & 1.0 & 0.8 & 1.0 & 0.7 & 0.8 & 0.9 & 1.0 & 0.3 & 0.5 & 1.0 & 1.0 & 0.9 & 0.1 & 0.9 & 1.0 & 1.0 & & \\
\hline $\mathrm{Sc}$ & 1.0 & 0.9 & 1.0 & 0.8 & 0.8 & 0.9 & 1.0 & 0.4 & 0.6 & 1.0 & 1.0 & 0.9 & 0.2 & 0.9 & 1.0 & 1.0 & 1.0 & \\
\hline$S$ & 0.9 & 0.8 & 0.9 & 0.8 & 0.8 & 1.0 & 0.9 & 0.4 & 0.5 & 0.9 & 0.9 & 0.9 & 0.2 & 0.7 & 0.9 & 0.9 & 0.9 & 1.0 \\
\hline
\end{tabular}


Table 6. Principal component analyses of elements in sediments of Ologe lagoon.

\begin{tabular}{|c|c|c|}
\hline Elements & Factor 1 & Factor 2 \\
\hline $\mathrm{Cu}$ & 0.99 & \\
\hline $\mathrm{Pb}$ & 0.74 & 0.40 \\
\hline $\mathrm{Ni}$ & 0.97 & \\
\hline Co & 0.68 & 0.37 \\
\hline $\mathrm{Mn}$ & 0.70 & 0.41 \\
\hline $\mathrm{Fe}$ & 0.91 & \\
\hline Th & 1.04 & \\
\hline $\mathrm{Ca}$ & & 0.96 \\
\hline $\mathrm{P}$ & 0.34 & 0.76 \\
\hline $\mathrm{La}$ & 0.97 & \\
\hline $\mathrm{Cr}$ & 1.00 & \\
\hline $\mathrm{Mg}$ & 0.91 & \\
\hline $\mathrm{Ba}$ & & 1.00 \\
\hline $\mathrm{Ti}$ & 0.98 & \\
\hline $\mathrm{Al}$ & 1.00 & \\
\hline $\mathrm{K}$ & 1.00 & \\
\hline Sc & 1.00 & \\
\hline S & 0.92 & \\
\hline \multicolumn{3}{|l|}{ Eigenvalues } \\
\hline Total & 14.35 & 2.41 \\
\hline$\%$ of Variance & 79.71 & 13.40 \\
\hline Cumulative \% & 79.71 & 93.11 \\
\hline Total & 14.09 & 5.45 \\
\hline
\end{tabular}

the Ologe lagoon is illustrated in Figure 3. Generally, the heavy metals concentration fluctuated with depth and were observed to be depleted at the shallow depth $(0$ and $10 \mathrm{~cm})$ in stations S1, S4, S5 and S6 suggesting the impacts of sand dredging activities within the lagoon. Naturally, elements accumulate more within the first $10 \mathrm{~cm}$ of the profile, due to adsorption to organic materials and relatively immobility (Ong \& Kamaruzzaman, 2009). Cu, Cr, Mn and Ni were observed to be greatly accumulated at the top of the sediments in the profile S4.

\subsection{Contamination Indices in the Sediments}

\subsubsection{Enrichment Factor}

Enrichment factor was calculated using $\mathrm{Al}$ due to its wide usage as a reference material. The element was also used because it is present in the environment in small quantities (Loska \& Wiechula, 2003). The result of the EF of the sediments classified and presented in Table 7 . The result showed that $\mathrm{Cr}$ and $\mathrm{Cu}$ are 

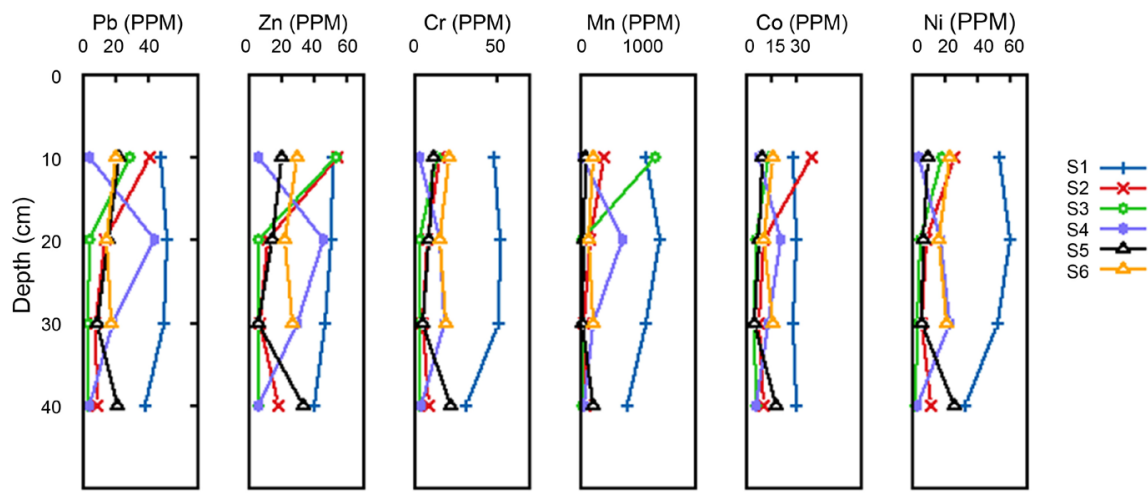

Figure 3. Distribution of heavy metal concentration with depth across sample points (S1, S2, S3, S4, S5 and S6) in Ologe lagoon.

Table 7. Classification of enrichment factor in heavy metals from Ologe sediments.

\begin{tabular}{ccccc}
\hline & Mean & Min & Max & Description \\
\hline $\mathrm{Cu}$ & 1.59 & 0.80 & 3.87 & minimal to moderately enriched \\
$\mathrm{Pb}$ & 3.07 & 1.82 & 6.30 & minimal to significantly enriched \\
$\mathrm{Zn}$ & 3.31 & 2.05 & 6.43 & moderate to significant \\
$\mathrm{Ni}$ & 1.03 & 0.72 & 1.52 & minimal enrichment \\
$\mathrm{Co}$ & 5.39 & 2.81 & 10.75 & moderate to significant \\
$\mathrm{Mn}$ & 3.36 & 1.04 & 14.46 & minimal to significantly enriched \\
$\mathrm{Cr}$ & 1.75 & 1.40 & 2.38 & minimal to moderately enriched \\
\hline
\end{tabular}

minimal to moderately enriched; $\mathrm{Pb}$ and $\mathrm{Mn}$ are minimal to significantly enriched; $\mathrm{Zn}$ and $\mathrm{Co}$ are moderate to significantly enriched while Ni has minimal enrichment. The result for enrichment factor shows the high presence of anthropogenic influence from industrial release of effluents into the Ologe Lagoon agreeing with the work of (Han et al., 2006; Edori \& Nna, 2018).

\subsubsection{Contamination Factor (CF)}

The contamination factor of $\mathrm{Cu}, \mathrm{Pb}, \mathrm{Zn}, \mathrm{Ni}, \mathrm{Co}, \mathrm{Mn}$, and $\mathrm{Cr}$ for all the samples collected from the lagoon ranged between $0.01-0.42,0.04-0.55,0.05-0.51$, $0.01-0.27,0.11-0.86,0.02-1.22$ and $0.02-0.44$ respectively. The values indicate low contamination of the sediments in the lagoon.

\subsubsection{Geo-Accumulation Index (Igeo)}

The Geo-accumulation $\left(\mathrm{I}_{\text {geo }}\right)$ values for all seven heavy metals $(\mathrm{Cu}, \mathrm{Pb}, \mathrm{Zn}, \mathrm{Ni}$, $\mathrm{Co}, \mathrm{Mn}$ and $\mathrm{Cr}$ ) in the sediments are presented in Table 8 and classified according to Muller (1969). The Igeo values for $\mathrm{Cu}$ and $\mathrm{Pb}$ in the stations ranged between 1 and 2.8 indicating moderately to strongly pollution in the sediments; Zn ranged from 2.5 to 3.5 and suggests a moderate to strong pollution levels; Co also shows a level of pollution of $\left(1.5\right.$ - 2.4) making it moderately polluted. $\mathrm{I}_{\mathrm{geo}}$ values for $\mathrm{Mn}$ indicates extremely pollution in all stations with values ranging between 4.1 and 5.8. Cr showed a moderate to strong level of pollution with values of between 2.2 and 3.5. 
Table 8. Geo-accumulation index of different heavy metals in Ologe lagoon.

\begin{tabular}{ccc}
\hline Elements & $\mathrm{I}_{\text {geo }}$ Range & Description \\
\hline $\mathrm{Cu}$ & $1-2.8$ & From moderately polluted to extremely polluted \\
$\mathrm{Pb}$ & $1-8.7$ & Moderately polluted to extremely polluted \\
$\mathrm{Zn}$ & $2.5-3.5$ & From moderately to Strongly polluted \\
$\mathrm{Ni}$ & $1.6-3.1$ & From moderately polluted to strongly polluted \\
$\mathrm{Co}$ & $1.5-2.4$ & Moderately polluted \\
$\mathrm{Mn}$ & $4.1-5.8$ & From strongly polluted to extremely polluted \\
$\mathrm{Cr}$ & $2.2-3.5$ & From moderately polluted to strongly polluted \\
\hline
\end{tabular}

\section{Conclusion}

This study showed that the Lagoon accumulates toxic metals as a result of anthropogenic activities evident in the dumping of municipal and industrial waste and showed that Ologe Lagoon is a major sink for effluents from Agbara Industrial Estate. The heavy metal contents in the Lagoon sediments $\mathrm{Cu}, \mathrm{Pb}, \mathrm{Zn}, \mathrm{Ni}$, $\mathrm{Co}, \mathrm{Mn}, \mathrm{Cr}, \mathrm{Al}$ concentrations were taken in Part per Million (PPM) ratio with an average concentration of metals in each station. Based on Sediment Quality Guidelines, the abundance of $\mathrm{Cu}, \mathrm{Pb}, \mathrm{Zn}, \mathrm{Ni}, \mathrm{Co}, \mathrm{Mn}, \mathrm{Cr}$ and $\mathrm{Mn}$ in the Ologe Lagoon suggests moderate pollution with only Mn having strongly to extremely polluted values. The anthropogenic sources of this metal include municipal waste discharges, sewage sludge, and mineral processing (smelting). The sediments of Ologe Lagoon have a range of minimal to extremely high enrichment of $\mathrm{Cu}, \mathrm{Pb}, \mathrm{Zn}, \mathrm{Ni}, \mathrm{Co}, \mathrm{Mn}, \mathrm{Cr}$, and $\mathrm{Al}$. Cr showed the highest level of enrichment in Station 1 while other stations were of significant levels of enrichment. The mean values of 7 elements $(\mathrm{Cu}, \mathrm{Pb}, \mathrm{Zn}, \mathrm{Ni}, \mathrm{Co}$ and $\mathrm{Mn})$ have a strong positive correlation or relationship with each other. The good and strong positive correlations indicate that the heavy metals in Ologe Lagoon might have a common source which is likely anthropogenic origin. The abundance of $\mathrm{Mn}$ may be attributed to anthropogenic activities especially from the metal dumps sites and smelting industry. The mean concentration of Mn was more than the sediment quality guidelines thus making it a pollutant to the environment. Environmental monitoring of the Ologe Lagoon is highly recommended.

\section{Conflicts of Interest}

The authors declare no conflicts of interest regarding the publication of this paper.

\section{References}

Alloway, B. J. (Ed.). (2012). Heavy Metals in Soils: Trace Metals and Metalloids in Soils and Their Bioavailability (Vol. 22). Berlin: Springer Science \& Business Media.

Anetekhai, M. A., Akin-Oriola, G. A., Aderinola, O. J., \& Akintola, S. L. (2007). Trace Metal Concentration in Macrobrachium vollenhovenii from Ologe Lagoon, Lagos, Ni- 
geria. Journal of Afrotropical Zoology, 25-29.

Bloomfield, C., Kelso, W. I., \& Pruden, G. (1976). Reactions between Metals and Humified Organic Matter. Journal of Soil Science, 27, 16-31. https://doi.org/10.1111/j.1365-2389.1976.tb01971.x

Bosman, C., \& Kidd, M. (2009). Water Pollution. In H. Strydom, \& N. King (Eds.), Environmental Management in South Africa (pp. 630-695). Cape Town: Juta and Company Ltd.

Bryan, G. W. (1976). Some Aspects of Heavy Metal Tolerance in Aquatic Organisms. In A. P. M. Lockhood (Ed.), Effects of Pollutants on Aquatic Organisms (p. 193). Cambridge: Cambridge University Press.

Connell, D., Lam, P., Richardson, B., \& Wu, R. (1999). Introduction to Ecotoxicology (71 p.). Oxford: Blackwell Science Ltd.

Duffus, J. (2002). Heavy Metals-A Meaningless Term. Pure Applied Chemistry, 74, 793-807. https://doi.org/10.1351/pac200274050793

Edori, O. S., \& Nna, P. J. (2018). Determination of Physicochemical Parameters of Effluents at Discharge Points into the New Calabar River along Rumuolumeni Axis, Port Harcourt, Rivers State, Niger Delta, Nigeria. Journal of Environmental and Analytical Toxicology, 8, 585.

Hakanson, L. (1980). An Ecological Risk Index for Aquatic Pollution Control. A Sedimentological Approach. Water Research, 14, 975-1001.

https://doi.org/10.1016/0043-1354(80)90143-8

Han, Y., Du, P., Cao, J., \& Posmentier, E. S. (2006). Multivariate Analysis of Heavy Metal Contamination in Urban Dusts of Xi'an, Central China. Science of the Total Environment, 355, 176-186. https://doi.org/10.1016/j.scitotenv.2005.02.026

Hariprasad, N., \& Dayananda, H. (2013). Environmental Impact Due to Agricultural Runoff Containing Heavy Metals-A Review. International Journal of Scientific and Research Publications, 3, 1-6

Ita, R. E., \& Anwana, E. D. (2017). Geochemical Assessment of Heavy Metal Contamination in Rural and Urban Wetlands in Akwa Ibom State, Nigeria. New York Science Journal, 10, 43-51.

Kumolu-Johnson, C. A., Ndimele, P. E., Akintola, S. L., \& Jibuike, C. C. (2010). Copper, Zinc and Iron Concentrations in Water, Sediment and Cynothrissa mento (Regan 1917) from Ologe Lagoon, Lagos, Nigeria: A Preliminary Survey. African Journal of Aquatic Science, 35, 87-94. https://doi.org/10.2989/16085914.2010.466588

Kusemiju, V., Fadiya, A. A., Aderinola, O. J., \& Akintola, S. L. (2001). Comparative Analysis of Heavy Metals in Water, Sediments and Tissues of Lumbricus violaceus from Agbara and Iba Streams. Nigerian Journal of Research and Review in Science, 2, 114-117.

Loizidou, M., Haralambous, K. J., \& Sakellarides, P. O. (1992). Environmental Study of the Marians Part II. A Study on the Removal of Metals from the Marianas Sediments. Environmental Technology, 13, 245-252. https://doi.org/10.1080/09593339209385150

Loska, K., \& Wiechula, D. (2003). Application of Principal Component Analysis for the Estimation of Source Heavy Metal Contamination in Surface Sediments from Rybnik Reservoir. Chemosphere, 51, 723-733. https://doi.org/10.1016/S0045-6535(03)00187-5

Mico, C., Recatala, L., Peris, M., \& Sanchez, J. (2006). Assessing Heavy Metal Sources in Agricultural Soils of an European Mediterranean Area by Multivariate Analysis. Chemosphere, 65, 863-872. https://doi.org/10.1016/j.chemosphere.2006.03.016

Mmolawa, K. B., Likuku, A. S., \& Gaboutloeloe, G. K. (2011). Assessment of Heavy Metal 
Pollution in Soils along Major Roadside Areas in Botswana. African Journal of Environmental Science and Technology, 5, 186-196.

Muller, G. (1969). Index of Geoaccumulation in Sediments of the Rhine River. Journal of Geology, 2, 109-118.

Ong, M. C., \& Kamaruzzaman, B. Y. (2009). An Assessment of Metals ( $\mathrm{Pb}$ and Cu) Contamination in Bottom Sediment from South China Sea Coastal Waters, Malaysia. American Journal of Applied Sciences, 6, 1418-1423. https://doi.org/10.3844/ajassp.2009.1418.1423

Scott, R. O., Ure, A. M., Philp, J. M., Glynn, J. P., McLean, W. R., Stanton, D. L., \& West, T. S. (1972). Some Sources of Contamination in Trace Analysis. Proceedings of the Society for Analytical Chemistry, 9, 288-303. https://doi.org/10.1039/sa9720900288

Sinex, S. A., \& Helz, G. R., (1981). Regional Geochemistry of Trace Elements in Chesapeake Bay. Journal of Environmental Geography, 3, 315-323. https://doi.org/10.1007/BF02473521

Smith, D. (1985). Sources of Heavy Metal Input to the New Zealand Aquatic Environment. Journal of the Royal Society of New Zealand, 15, 371-384.

https://doi.org/10.1080/03036758.1985.10421714

Tippie, V. K. (1984). An Environmental Characterization of Chesapeake Bay and a Frame Work for Action. In V. Kennedy (Ed.), The Estuary as a Filter (pp. 467-487). New York: Academic Press. https://doi.org/10.1016/B978-0-12-405070-9.50028-1

Turekian, K. K., \& Wedepohl, K. H. (1961). Distribution of the Elements in Some Major Units of the Earth's Crust. Geological Society of America Bulletin, 72, 175-192. https://doi.org/10.1130/0016-7606(1961)72[175:DOTEIS]2.0.CO;2

USEPA (1999). USEPA Reference Methodology Standard Opening Procedure for the Digestion of Soil/Sediment Sample Using a Hot Plate/Beaker Digestion Technique, Chicago, IL. SW-846.

Zheng, N., Wang, Q., Zhang, X., Zheng, D., Zhang, Z., \& Zhang, S. (2007). Population Health Risk Due to Dietary Intake of Heavy Metals in the Industrial Area of Huludao City, China. Science of the Total Environment, 387, 96-104.

https://doi.org/10.1016/j.scitotenv.2007.07.044 